\title{
MONETARY POLICY RULES AND MACROECONOMIC STABILITY: EVIDENCE AND SOME THEORY
}

\author{
RICHARD CLARIDA, JORDI GALÍ, AND MARK GERTLER*
}

May 1999

First draft: March 1997

\begin{abstract}
We estimate a forward-looking monetary policy reaction function for the postwar United States economy, before and after Volcker's appointment as Fed Chairman in 1979. Our results point to substantial differences in the estimated rule across periods. In particular, interest rate policy in the Volcker-Greenspan period appears to have been much more sensitive to changes in expected inflation than in the pre-Volcker period. We then compare some of the implications of the estimated rules for the equilibrium properties of inflation and output, using a simple macroeconomic model, and show that the Volcker-Greenspan rule is stabilizing.
\end{abstract}

Keywords: monetary policy rules, business cycles, Taylor rules, sunspot fluctuations.

JEL Classification Numbers: E32, E52

\footnotetext{
${ }^{*}$ We thank seminar participants at Universitat Pompeu Fabra, New York University, Federal Reserve Board, University of Maryland, NBER Summer Institute, Université de Toulouse, Bank of Spain, Harvard University, Bank of Mexico, Universitat de Girona, and the Federal Reserve Banks of Atlanta, New York, Richmond, Dallas, and Philadelphia, as well as two anonymous referees and two editors for useful comments. Tommaso Monacelli provided valuable research assistance. The second and third authors are grateful to the C.V. Starr Center (Gali and Gertler) and CREI (Galí) for financial support.
} 


\section{Introduction}

From the late 1960s through the early 1980s, the United States economy experienced high and volatile inflation along with several severe recessions. Since the early 1980s, however, inflation has remained steadily low, while output growth has been relatively stable. Many economists cite supply shocks - and oil price shocks, in particular - as the main force underlying the instability of the earlier period. It is unlikely, however, that supply shocks alone could account for the observed differences between the two eras. For example, while jumps in the price of oil might help explain transitory periods of sharp increases in the general price level, it is not clear how they alone could explain persistent high inflation in the absence of an accommodating monetary policy. ${ }^{1}$ Furthermore, as De Long [1997] argues, the onset of sustained high inflation occurred prior to the oil crisis episodes.

In this paper we explore the role of monetary policy. We first demonstrate that there is a significant difference in the way monetary policy was conducted pre- and post-1979, the year Paul Volcker was appointed Chairman of the Federal Reserve Board. We then go on to argue that this difference could be an important source of the shift in macroeconomic behavior. In some ways, our story should not be surprising. Many economists agree that monetary policy in the United States has been relatively well managed from the time Paul Volcker took over the helm, through the current regime of Alan Greenspan. It is also generally agreed that monetary policy was not so well managed in the fifteen years or so prior to Volcker. ${ }^{2}$ The contribution of our paper is to add precision to this conventional wisdom.

We identify how monetary policy differed before and after Volcker came to office by estimating policy rules for each era. Specifically, we estimate a general type of rule that treats the Federal Funds rate as the instrument of monetary policy. The

\footnotetext{
${ }^{1}$ In section III.D, we provide more detail on the role of oil shocks versus monetary policy and also on how the monetary policy rule influences the effects that oil shocks have on the economy.

${ }^{2}$ See, e.g., the recent discussions in Friedman and Kuttner [1996] and Gertler [1996].
} 
rule calls for adjustment of the Funds rate to the gaps between expected inflation and output and their respective target levels. It is a version of the kind of policy rule that emerges in both positive and normative analyses of central bank behavior that have appeared in recent literature. ${ }^{3}$ A distinctive feature of our specification is that it assumes forward-looking behavior on the part of the central bank.

The key difference in the estimated policy rules across time involves the response to expected inflation. We find (not surprisingly) that the Federal Reserve was highly "accommodative" in the pre-Volcker years: On average, it let real short term interest rates decline as anticipated inflation rose. While it raised nominal rates, it typically did so by less than the increase in expected inflation. On the other hand, during: the Volcker-Greenspan era the Federal Reserve adopted a proactive stance toward controlling inflation: it systematically raised real as well as nominal short term interest rates in response to higher expected inflation. Our results thus lend quantitative support to the popular view that not until Volcker took office did controlling inflation become the organizing focus of monetary policy.

The second part of the paper presents a theoretical model designed to flesh out how the observed changes in the policy rule could account for the change in macroeconomic performance. We embed policy rules of the type we estimate within a fairly standard business cycle model and then analyze the dynamics of inflation and output in the resulting equilibrium. We show that the estimated rule for the pre-Volcker period permits greater macroeconomic instability than does the Volcker-Greenspan rule. It does so in two distinct respects:

First, the pre-Volcker rule leaves open the possibility of bursts of inflation and output that result from self-fulfilling changes in expectations. These sunspot fluctuations may arise under this rule because individuals (correctly) anticipate that the Federal Reserve will accommodate a rise in expected inflation by letting short term real interest rates decline (which in turn stimulates the rise in aggregate demand

\footnotetext{
${ }^{3}$ See Clarida, Galí, and Gertler [1999] for a review of the recent literature on monetary policy.
} 
and inflation). ${ }^{4}$ On the other hand, self-fulfilling fluctuations cannot occur under the estimated rule for the Volcker-Greenspan era since, within this regime, the Federal Reserve adjusts interest rates sufficiently to stabilize any changes in expected inflation. Second, the pre-Volcker rule is less effective than the Volcker-Greenspan rule at mitigating the impact of fundamental shocks to the economy. That is, holding constant the volatility of exogenous fundamental shocks, the economy exhibits greater stability under the post-1979 rule than under a rule that closely approximates monetary policy pre-1979.

The plan of the paper is as follows. Section II presents our policy rule specification, and discusses the econometric procedure used to estimate it. Section III reports estimates of this rule for different sample periods, conducts a number of robustness checks, and identifies the main differences in the coefficient estimates across periods. Section IV presents the theoretical model: a (now) conventional New Keynesian framework with money, monopolistic competition, and sticky prices. We then present both a qualitative and quantitative analysis of the model under the pre- and post 79 policy rules. Section V offers concluding remarks. Here we discuss an important issue that the paper raises but does not resolve: why in the pre-Volcker period the Federal Reserve appeared to pursue a systematic policy rule that not only accommodated inflation, but did so in a way that was entirely predictable by the private sector (at least with the benefit of hindsight).

\footnotetext{
${ }^{4}$ Chari, Christiano and Eichenbaum (1997) also suggest that the inflation of the 1970s may have mainly been due to self-fulfulling behavior. Their argument exploits the idea that there may be a multiplicity of equilibria in reputational models of monetary policy. Our analysis is based simply on the implications of the estimated historical policy reaction function.
} 


\section{The Federal Reserve's Policy Reaction Function: A Forward Looking Model}

\section{A. A Simple Forward Looking Rule}

We begin with a baseline specification of the policy reaction function. We take as the instrument of monetary policy the Federal Funds rate. Fxcept possibly for a brief period of reserves targeting at the start of the Volcker era, this seems a reasonable choice (see, e.g., Bernanke and Mihov [1998]). Further, Goodfriend [1991] argues that even under the period of official reserves targeting; the Federal Reserve had in mind an implicit target for the Funds rate.

The baseline policy rule we consider takes a simple form. Let $r_{t}^{*}$ denote the target rate for the nominal Federal Funds rate in period $t$. The target rate each period is a function of the gaps between expected inflation and output and their respective target levels. Specifically, we postulate the linear equation:

$$
r_{t}^{*}=r^{*}+\beta\left(E\left[\pi_{t, k} \mid \Omega_{t}\right]-\pi^{*}\right)+\gamma E\left[x_{t, q} \mid \Omega_{t}\right]
$$

where $\pi_{t, k}$ denotes the percent change in the price level between periods $t$ and $t+k$ (expressed in annual rates). $\pi^{*}$ is the target for inflation. $x_{t, q}$ is a measure of the average output gap between period $t$ and $t+q$, with the output gap being defined as the percent deviation between actual GDP and the corresponding target. ${ }^{5} E$ is the expectation operator, and $\Omega_{t}$ is the information set at the time the interest rate is set. $r^{*}$ is, by construction, the desired nominal rate when both inflation and output are at their target levels.

The policy rule given by (1) has some appeal on both theoretical and empirical grounds. Approximate (and in some cases exact) forms of this rule are optimal for a

\footnotetext{
5 The flow nature of GDP forces us to be more precise here: $x_{t, q}$ includes GDP gener ated between the beginning of period $t$ and the beginning of period $t+q$ (i.e., it includes periods (e.g., quarters) $t, t+1, \ldots$ and $t+q-1)$. In our empirical work, we account for the fact that period $t$ GDP is not known as of the time the interest rate is set in that period, i.e., $x_{t, 1} \notin \Omega_{t}$. This is not true in our theoretical model of section IV, where all variables dated in period $t$ are determined simultaneously.
} 
central bank that has a quadratic loss function in deviations of inflation and output from their respective targets, given a generic macroeconomic model with nominal price inertia. $^{6}$

On the empirical side, a number of authors have emphasized that policy rules like (1) provide reasonably good descriptions of the way major central banks around the world behave, at least in recent years. It is true that the most notable of these papers, Taylor [1993], proposes a rule where the Funds rate responds to lagged inflation and output rather than their expected future values. However, our forward looking rule nests the Taylor rule as a special case: If either lagged inflation or a linear combination of lagged inflation and the output gap is a sufficient statistic for forecasting future inflation then equation (1) collapses to the Taylor rule. ${ }^{7}$ On the other hand, our forward looking specification allows the central bank to consider a broad array of information (beyond lagged inflation and output) to form beliefs about the future condition of the economy, a feature which we find highly realistic.

\section{B. Implied Real Rate Rule}

The implications of a policy rule like (1) for the cyclical behavior of the economy will of course depend on the sign and magnitude of the slope coefficients, $\beta$ and $\gamma$. To gain the basic intuition, consider the implied rule for the (ex-ante) real rate target, $r r_{t}^{*}$ :

$$
r r_{t}^{*}=r r^{*}+(\beta-1)\left(E\left[\pi_{t, k} \mid \Omega_{t}\right]-\pi^{*}\right)+\gamma E\left[x_{t, q} \mid \Omega_{t}\right]
$$

where $r r_{t}^{*} \equiv r_{t}-E\left[\pi_{t, k} \mid \Omega_{t}\right]$ and where $r r^{*} \equiv r^{*}-\pi^{*}$ is the long run equilibrium real rate. ${ }^{8}$ We assume that the real rate is stationary and is determined by non-monetary

\footnotetext{
${ }^{6}$ See, e.g., Svensson [1996], and Clarida, Galí, and Gertler [1999].

${ }^{7}$ In this case, however, the estimated coefficients of the Taylor rule may be misleading as indicators of the Fed's intended response to inflation and output changes since, in addition to the size of the policy response, they capture the ability of each variable to forecast the state of the economy.

${ }^{8}$ Note that $r r_{t}^{*}$ is an "approximate" real rate since the forecast horizon for inflation will generally differ from the maturity of the short term nominal rate used as a monetary policy instrument. In practice this is of little relevance, given the high correlation among short term rates at maturities
} 
factors in the long run, consistent with conventional wisdom. ${ }^{9}$ Accordingly, $r r^{*}$ is a constant and is independent of monetary policy. ${ }^{10}$

As equation (2) makes clear, the sign of the response of the real rate target to changes in expected inflation and the output gap depends on whether $\beta$ is greater or less than one and on the sign of $\gamma$, respectively. Roughly speaking, to the extent that lower real rates stimulate economic activity and inflation (as implied by standard macroeconomic models and as perceived by policymakers and market participants alike), interest rate rules characterized by $\beta>1$ will tend to be stabilizing, while those with $\beta \leq 1$ are likely to be destabilizing or, at best, accommodative of shocks to the economy. ${ }^{11}$ A similar logic applies to the sign of $\gamma$ (i.e.e, stabilizing if $\gamma>$ 0 ; destabilizing if $\gamma \leq 0)$. We thus have benchmarks $(\beta=1, \gamma=0)$ to evaluate differences in the estimated policy rules across time

\section{Interest Rate Smoothing and Exogenous Shocks}

Absent any further modification, the policy reaction function given by equation (1) is too restrictive to describe actual changes in the Funds rate. There are at least three associated with plausible target horizons. Hence, e.g., the correlation between the federal funds rate and the 3- months Treasury Bill rate (our baseline horizon) is 0.982 in our sample.

${ }^{9}$ In our empirical work, however, we allow for the possibility that there have been shifts over time in the long run equilibrum real rate, since we assume only that in $r r^{*}$ is constant within the sub-period over which we estimate.

${ }^{10}$ In our empirical work we allow for changes in the equilibrium real rate across subperiods.

${ }^{11}$ Another way to model accommodation of inflation would to be allow for endogenous adjustment of the target inflation rate, $\pi^{*}$. We view this approach as a sympathetic alternative to the one we take of focusing on whether the slope coefficient $\beta$ is less than unity. We opt to treat $\pi^{*}$ as a constant and instead let $\beta$ characterize the degree of accommodation for two reasons: First, this approach has the advantage of parsimony - there is no need to model the adjustment of $\pi^{*}$. Second, as a matter of logic, it is a priori reasonable to treat $\pi^{*}$ as constant since it is meant to reflect an optimum for inflation that is independent of current economic conditions. In our robustness exercises, however, we do let $\pi^{*}$ vary within each sub-sample. To foreshadow, we find that the magnitude of $\beta$ seems to do a better job of capturing the degree of accommodation than any time variation in $\pi^{*}$, consistent with the approach we take. 
reasons why. First, the specification assumes an immediate adjustment of the actual Funds rate to its target level, and thus ignores the Federal Reserve's tendency to smooth changes in interest rates. ${ }^{12}$ Second, it treats all changes in interest rates over time as reflecting the Federal Reserve's systematic response to economic conditions. Specifically, it does not allow for any randomness in policy actions, other than that associated with mis-forecasts of the economy. Third, it assumes that the Federal Reserve has perfect control over interest rates, i.e., it succeeds in keeping them at the desired level (e.g., through necessary open market operations).

We relax these assumptions by extending the model in a straightforward way. In particular we specify the following relationship for the actual Funds rate, $r_{t}$ :

$$
r_{t}=\rho(L) r_{t-1}+(1-\rho) r_{t}^{*}
$$

where $\rho(L)=\rho_{1}+\rho_{2} L+\ldots+\rho_{n} L^{n-1}$, and where $\rho \equiv \rho(1) . \quad v_{t}$ is a zero mean exogenous interest rate shock, and the Funds rate target $r_{t}^{*}$ is given by (1). Equation (3) postulates partial adjustment of the Funds rate to the target $r_{t}^{*}$. Specifically, each period the Federal Reserve adjusts the Funds rate to eliminate a fraction $(1-\rho)$ of the gap between its current target level and some linear combination of its past values. We interpret $\rho$ as an indicator of the degree of smoothing of interest rate changes.

Combining the partial adjustment equation (3) with the target model (1) yields the policy reaction function

$$
r_{t}=(1-\rho)\left[r r^{*}-(\beta-1) \pi^{*}+\beta \pi_{t, k}+\gamma x_{t, q}\right]+\rho(L) r_{t-1}+\varepsilon_{t}
$$

where $\varepsilon_{t} \equiv-(1-\rho)\left\{\beta\left(\pi_{t, k}-E\left[\pi_{t, k} \mid \Omega_{t}\right]\right)+\gamma\left(x_{t, q}-E\left[x_{t, q} \mid \Omega_{t}\right]\right)\right\}$. Notice that the term in curly brackets is a linear combination of forecast errors and is thus orthogonal to any variable in the information set $\Omega_{t}$.

\footnotetext{
${ }^{12}$ See also Rudebusch [1995] for evidence on the serial correlation of interest rate changes. Why this smoothing occurs is beyond the scope of this paper, though a number of explanations are found in the literature, including fear of disruption of financial markets (Goodfriend [1991]), or uncertainty about the effects of interest rate changes (Sack [1997]).
} 
Let $\mathbf{z}_{t}$ denote a vector of instruments known when $r_{t}$ is set (i.e., $\mathbf{z}_{t} \in \Omega_{t}$ ). Equation (4) then implies the set of orthogonality conditions

$$
E\left\{\left[r_{t}-(1-\rho)\left(r r^{*}-(\beta-1) \pi^{*}+\beta \pi_{t, k}+\gamma x_{t, q}\right)+\rho(L) r_{t-1}\right] \mathbf{z}_{t}\right\}=0
$$

which provide the basis for the estimation of the parameter vector $(\alpha, \beta, \gamma, \rho)$, using the Generalized Method of Moments (Hansen [1982]), with an optimal weighting matrix that accounts for possible serial correlation in $\left\{\varepsilon_{t}\right\} .{ }^{13}$ To the extent that the dimension of vector $\mathbf{z}_{t}$ exceeds four-the number of parameters being estimated-(5) implies some overidentifying restrictions that we can test in order to assess of the validity of our specification as well as the set of instruments used.

In the absence of further assumptions our approach only identifies the term $r r^{*}-$ $(\beta-1) \pi^{*}$, but not $r r^{*}$ or $\pi^{*}$ separately. Since target inflation $\pi^{*}$ is of some interest in our characterization of monetary policy, we impose an additional restriction that permits us to identify and estimate this parameter. Specifically, we take the observed sample average as a measure of the equilibrium real rate $r r^{*}$, an assumption which we view as providing a reasonable first approximation, given our sample size. Imposing this restriction directly in equation (5) allows us to estimate $\pi^{*}$ jointly with the parameter vector $(\alpha, \beta, \gamma, \rho)$. To demonstrate robustness, however, we also report estimates of $(\alpha, \beta, \gamma, \rho)$ that do not impose this additional restriction.

Before proceeding we briefly address several econometric issues. First, our empirical analysis maintains the assumption that both inflation and the nominal interest rate are stationary. We view this assumption as reasonable for the postwar United States, even though the null of a unit root in either variable is often hard to reject at conventional significance levels, given the persistence of both series and the well known low power of unit root tests. In addition to its empirical plausibility, stationarity of both inflation and the nominal interest rate is also a property of many of the theoretical models that rationalize the use of the kind of policy rule considered

\footnotetext{
${ }^{13}$ Note that, by construction, the first component of $\left\{\varepsilon_{t}\right\}$ follows an $M A(a)$ process, with $a=$ $\max [k, q]-1$, and will thus be serially correlated (unless $k=q=1$ ).
} 
here. ${ }^{14}$ In our robustness analysis, however, we do allow for the possibility of drift in the trend rate of inflation by letting the target inflation rate vary across the regimes of different Federal Reserve chairmen.

Second, the sample period must contain sufficient variation in inflation and output and must be sufficiently long in order to identify the slope coefficients in the policy reaction function, as well as the target inflation rate $\pi^{*}$. In particular, estimating the rule over a short sample with little variability in inflation can yield highly misleading results. Suppose, for example, that the Federal Reserve responds aggressively to large deviations of inflation from target but not to small deviations. Then by estimating over a period where inflation does not vary much from its target, one might mistakenly conclude that the Fed is not aggressive in fighting inflation (i.e.e, one might mistakenly obtain too low an estimate of $\beta$ ). Alternatively, suppose a central bank confronting high inflation is in the process of raising rates to engineering a disinflation. By estimating the rule only over the current period of high inflation, one might mistakenly conclude that the central bank has a high target inflation rate (i.e., one might mistakenly obtain too high an estimate of $\pi^{*}$ and, as a result, too low an estimate of $\beta)^{15}$ The subsamples we consider, however, appear to contain sufficient variation in inflation relative to the sample mean and are sufficiently long to permit us to correctly identify both the slope coefficient on inflation, $\beta$ and the target inflation rate $\pi^{*} \cdot{ }^{16}$.

\footnotetext{
${ }^{14}$ See, e.g., Clarida, Gali and Gertler [1999].

${ }^{15}$ The estimate of $\pi^{*}$ will depend heavily on the sample mean of inflation. Thus, estimating over a short period of above target inflation can generate too high an estimate of $\pi^{*}$. The overestimate of $\pi^{*}$ will be accompanied by an underestimate of $\beta$, since the former will account for the high nominal rates over the short period. By lengthening the sample to include the full disinflation and beyond, one will obtain an estimate of $\pi^{*}$ that is closer to the true target, and as a consequence a (higher) estimate of $\beta$ that is closer to its true value.

${ }^{16}$ When we consider sub-sample stability of our estimates in section III we address the short sample problem by restricting some coefficients to be constant across the sample (in the cases where we cannot reject the coefficient is stable.)
} 


\section{The Federal Reserve's Policy Reaction Function: the Evidence}

In this section we report estimates of the policy reaction function defined by equations (1) and (3). We accomplish two main objectives. First, we demonstrate the existence of a systematic relationship between the Funds rate and forecasts of future inflation and output along the lines suggested by our model. Second, we identify differences in the conduct of monetary policy pre- and post-1979. We do so by estimating monetary policy rules for each era and performing tests of structural stability across periods.

The data are quarterly time series spanning the period 1960:1-1996:4. With one exception, we obtain the data from CITIBASE (mnemonics follow in parentheses). We use as the interest rate the average Federal Funds rate (FYFF) in the first-month of each quarter, expressed in annual rates. The baseline inflation measure is the (annualized) rate of change of the GDP deflator (GDPP) between two subsequent quarters. But we also report results using CPI (PUNEW) inflation. The baseline "output gap" measure is the series constructed by the Congressional Budget Office (CBO). We also use two alternative measures (described below) based on the detrended series for GDP (GDPQ) and the unemployment rate (LHUR). The instrument set includes lags of the Funds rate, inflation, and the output gap, as well as the same number of lags of commodity price inflation (PSCCOM), M2 growth (FM2), and the "spread" between the long-term bond rate (FYGL) and the 3 -month Treasury Bill rate (FYGM3). ${ }^{17}$

We divide the sample into two main subperiods. The first (60:1-79:2), encompasses the tenures of William M. Martin, Arthur Burns, and G. William Miller as Federal Reserve chairmen. The second (79:3-96:4) corresponds to the terms of Paul Volcker and Alan Greenspan. As we discussed in the introduction, these subperiods roughly

\footnotetext{
${ }^{17}$ In closely related work, Orphanides [1997] estimates a reaction function using more direct measures of the Fed's perception of both the output gap and inflation, based on real time data. His results, by and large, confirm the results we obtain.
} 
correspond to the unstable and stable eras of recent macroeconomic history. This characterization, while simplistic, is clearly reflected in the data. Table I reports the standard deviation of inflation (levels and HP-detrended) and output (CBO gap and HP-detrended), for the two subperiods. The reduction in volatility appears substantial for each variable. Not surprisingly, the decline is more dramatic when we begin the second subperiod in 82:4, after Volcker disinflation, as the bottom row of the Table indicates.

\section{A. Baseline Estimates}

Table II reports GMM estimates of the interest rate rule parameters $\pi^{*}, \beta, \gamma$, and $\rho$ for each sample period, using the CBO output gap and GDP deflator inflation (our baseline variables). The target horizon is assumed to be one quarter for both inflation and the output gap. (i.e., $k=q=1$ ). Standard errors are reported in brackets. The right-most column reports the $p$-value associated with a test of the model's overidentifying restrictions (Hansen's J-test). The estimates are based on a specification of the interest rate rule with two lags of the interest rate $(n=2)$, which seemed to be sufficient to eliminate any serial correlation in the error term. Four lags of the instruments were used.

A number of interesting results stand out. Note first that the model is not rejected at conventional significance levels for any of the specifications or sample periods. The estimates of $\beta$ and $\gamma$, further, generally have the expected sign and are significant in most cases. These estimates also point to substantial differences in the policy reaction function across periods. Most importantly, the estimate of $\beta$, the coefficient associated with expected inflation, is significantly below unity for the pre-Volcker period ( 0.83 , with s.e. $=0.07$ ), and far greater than one for the Volcker-Greenspan period $(2.15$, with s.e. $=0.40)$. On the other hand, the estimates of $\gamma$-the coefficient measuring the sensitivity to the cyclical variable-are also significant in both periods, but only marginally so for the Volcker-Greenspan era. ${ }^{18}$

\footnotetext{
${ }^{18}$ See below for further discussion.
} 
The estimates of the inflation target, $\pi^{*}$, seem quite plausible in all cases: roughly four and a quarter percent pre-Volcker and three and half percent post- Volcker. While the point estimates reveal a slight downward trend over time, the difference is not significant. Based on this result and the estimates of $\alpha$ and $\beta$ across sub-samples, it does not seem to be the case that differences in monetary policy pre- and post- 1979 reflect simply differences in the target inflation rate. We shortly present some more evidence that bears on this issue that stems from an analysis of (within) sub-sample stability.

Finally, the estimate of the smoothing parameter $\rho$ is high in all cases, suggesting considerable interest rate inertia: Only between 10 and 30 percent of a change in the interest rate target is reflected in the Funds rate within the quarter of the change. Thus our estimates confirm the conventional wisdom that the Federal Reserve smooths adjustments in the interest rate.

To illustrate how well the model characterizes the behavior of the Funds rate, Figures I and II present the target rate estimates for each sub-period relative to the actual values of the Funds rate, using on our baseline estimates. In each subperiod, the target rate captures the broad swings in the actual rate reasonably well. Interestingly, during the 1987-1992 period that Taylor (1993) analyzes, our target rate tracks the actual rate about as well as does the simple Taylor rule. ${ }^{19}$

\section{B. Robustness Analysis}

We next explore the robustness of our results along a number of dimensions. We consider: (1) alternative measures of inflation and the output gap; (2) alternative target horizons for each variable; (3) relaxing the constraint on the intercept that allows us to identify $\pi^{*}$; (4) parameter stability within sub-samples; (5) a backward looking variation of our policy reaction function. We demonstrate that in each instance, the

\footnotetext{
${ }^{19}$ We stress that we are comparing the actual rate to the implied target rate, as opposed to the fitted model, which allows for partial adjustment. The fitted model, of course, would track the actual rate even more closely than does the target rate.
} 
insights from the baseline case remain intact.

\section{Alternative Measures}

We first re-estimate the reaction function using different measures of the output gap and inflation. We consider two alternative measures of the output gap: (a) the deviation of ( $\log )$ GDP from a fitted quadratic function of time; and (b) the deviation of the unemployment rate from a similar time trend, with the sign of the resulting series switched. ${ }^{20}$ Finally, we consider one alternative measure of inflation: the rate of change of the consumer price index (CPI).

Table III reports the estimates for the two main subperiods. The key results from the baseline case are robust to the use of alternative output gap and inflation measures. In fact, both the signs and magnitudes of the estimated parameters remain largely unchanged. There is, however, one minor difference: the estimated output gap coefficient for the Volcker-Greenspan subperiod, though positive, is now insignificant under the three specifications. At the same time, there remains a striking difference in the estimated slope coefficient for inflation across sub-periods: less than one before Volcker, greater than one under Volcker-Greenspan, with point estimates very close to those obtained in the baseline case.

\section{Alternative Horizons}

In the baseline case we assume that the Federal Reserve looks ahead one quarter for both inflation and the output gap. We now consider allowing for alternativeand, in our opinion, more realistic-target horizons for the same variables. Table IV reports results for $(k=4, q=1)$ as well as $(k=4, q=2)$, i.e. the Fed is assumed to have a target horizon of one year for its inflation target and of one (or two) quarters for the output. One formal rationale is that these horizons are roughly in line with the conventional wisdom regarding the lag with which monetary policy affects either variable (e.g., Bernanke and Mihov, 1998). In addition, these values as roughly consistent with informal discussions of policy tactics by Federal Reserve

\footnotetext{
${ }^{20}$ We switch the sign of the series in order to preserve the sign interpretation for parameter $\gamma$.
} 
officials. In either case, the results are qualitatively very similar to those reported in Table II.

\section{Unrestricted Intercept}

As we discussed, our approach identifies the inflation target $\pi^{*}$ by assuming that the equilibrium real rate $r r^{*}$ is known and equal to the observed average real rate over the relevant sample period. Here we relax that assumption and treat $r^{*}$ as unobserved, at the cost of leaving $\pi^{*}$ unidentified (only $\alpha \equiv r r^{*}-(\beta-1) \pi^{*}$ is identified). Table $\mathrm{V}$ reports the estimates for the remaining parameters thus obtained. The only significant difference relative to our baseline estimates of Table II is given by the insignificance of the output gap coefficient when the rule is estimated for the full Volcker-Greenspan sample period. This finding is reminiscent of that obtained when variables other than the baseline were used (see Table III).

\section{Subsample Stability}

We next explore the stability of parameters within each sub-sample. Among other things, this exercise permits us to relax the assumption that the inflation target $\pi^{*}$ is constant within the estimation period. It is conceivable, for example, that there was an upward shift in the target during the period of rising inflation in the 1970s.

A simple and natural way to proceed is to assume that the policy reaction function is stable during the tenure of the Federal Reserve chairman in charge at the time, but may vary across Chairmen. If we tack the brief period of Miller (78:1-79:3) on to Burns (70:1-78:1), then each sub-period may be divided into two regimes of roughly equal length. For the pre-1979 sample we thus have: Martin (60:1-69:4) and BurnsMiller (70:1-79:2). For the post-1979: Volcker (79:3-86:4) and Greenspan (87:1-96:4).

As discussed earlier, estimating the policy rule over short samples can generate imprecise estimates, given the limited number of observations. Accordingly, we adopt

the following procedure: We first estimate the reaction function for each baseline period (pre-Volcker or Volcker-Greenspan), but allowing for a shift across Chairmen in each of the coefficients (by means of appropriate dummies). Second, we re-estimate 
the rule after constraining all the parameters for which the shift was found to be insignificant in the first stage to be constant across Chairmen, while allowing for changes in the remaining parameters. The resulting estimates are reported in Table VI. We present estimates for two different target horizons for inflation and the output gap: $(1,1)$ and $(4,1) \cdot{ }^{21}$

Consider first the pre-Volcker period. Interestingly, no significant difference arises across Chairmen in either the value of the inflation target $\pi^{*}$, or in the inflation coefficient $\beta$. The point estimates for the inflation target (in the 5-7 percent range) are somewhat above the baseline estimates for the full pre-Volcker sample, though not significantly since the standard errors are now rather large. The estimated value for the inflation coefficient is below unity and is in line with the baseline estimates. The only notable departure from the baseline case is that the output gap coefficient is insignificant under Martin's tenure, but positive and significant under Burns and Miller.

Our procedure detects few robust differences across the Volcker and Greenspan eras. As in the pre-Volcker era, the estimates $\pi^{*}$ and $\beta$ are stable across chairmen. Estimates for each parameter, further, are close to those obtained in the baseline case. With a one-period horizon for both inflation and the output gap, the coefficient on the latter is close to zero (and insignificant) under Volcker, but is positive and significant under Greenspan. On the other hand, when the target horizon for inflation is four quarters, this difference vanishes. The estimated common value is positive and significant. In addition, the estimates under the $(4,1)$ horizon point to a significant increase in the degree of smoothing of interest rate changes under Greenspan, as reflected in the significantly higher estimate of the parameter $\rho$.

As a final check on subsample stability we explore the effects of removing the first three years of the Volcker era from the entire Volcker-Greenspan sample. There are at

\footnotetext{
${ }^{21}$ Since we also dummy all the instruments, we only use only two instrument lags in our subsample stability analysis, thus keeping the total number of instruments (and the degrees of freedom) comparable to the other specifications.
} 
least two reasons for doing this. First, this period was characterized by a sharp, oneshot disinflation episode, which brought inflation down from roughly 10 percent in 1980 to 4 percent in 1983, a level around which it stabilized. Second, over the period 1979:4 - 1982:4, the operating procedures of the Federal Reserve involved targeting: non-borrowed reserves as opposed to the Federal Funds rate. ${ }^{22}$ In order to make sure that neither of those features are over-influencing our estimates for the VolckerGreenspan period, we re-estimate the reaction function for the period 82:4-96:4, thus excluding the period of non-borrowed reserves targeting. The corresponding results, for two alternative horizons, are shown in the bottom panel of Table VI.

Once again, the estimates of $\beta$-the coefficient associated with expected inflationare above unity and not statistically different from the baseline case (though the estimate for the $(1,1)$ horizon is noisy $)^{23}$. On the other hand, the estimates of $\gamma$-the coefficient measuring the sensitivity to the cyclical variable-all become very small and insignificant when we use post-82 data (in contrast with our results for the full Volcker-Greenspan period). Thus, here we cannot reject the hypothesis that the Fed has effectively pursued a "pure inflation targeting" policy.

In sum, the key insights obtained the baseline case are robust to allowing for structural changes across Chairmen. In particular, the striking difference in the reaction

\footnotetext{
${ }^{22}$ As we noted earlier, Goodfriend (1991) argues forcefully that the Federal Reserve did indeed choose targets for non-borrowed reserves over this period ultimately with an objective for the path of the interest rate in mind. Nevertheless, Bernanke and Mihov [1998] present evidence that over the 1979:10 - 1982 period non-borrowed reserves was the operating instrument of monetary policy, which accords with conventional wisdom. For the rest of the time they show it is reasonable to treat the Federal Funds rate as the instrument of monetary policy. In a companion paper, Clarida, Gali and Gertler [1997b], we show that our baseline specification is robust to allowing for the possibility that the Fed may respond to money growth independently of its predictive power for inflation. That is, we reject the hypothesis that the Fed was targeting money growth. Our results are thus consistent with Friedman and Kuttner [1996].

${ }^{23}$ If we do not restrict the intercept to identify $\pi^{*}$, then the estimate of $\beta$ is significantly above unity and tightly estimated for the $(1,1)$ horizon, as well as for the $(4,1)$ horizon.
} 
function across time is the rise in the slope coefficient on inflation from slightly less than unity pre-Volcker to around two in the Volcker-Greenspan era.

\section{Backward looking estimates}

We complete our robustness analysis by reporting the estimates for different subperiods of a backward looking rule of the sort considered by Taylor [1993]. Our version of that rule corresponds to specification (4) with both $k$ and $q$ set to -1 . Table VII reports the corresponding results. All the qualitative features of our baseline specification estimates seem to hold here as well, suggesting that they are not inherent to the forward looking specification of the interest rate rule. In sum, while we view the forward looking specification as more plausible a priori, our key insights also obtain from the backward looking specification.

\section{Discussion of the Empirical Results}

Overall, our estimates point to the existence of important differences across periods in the sensitivity of monetary policy. This result, further, appears to be a robust feature of the data. Specifically, during the pre-Volcker period, in response to forecastable inflationary pressures, the Federal Reserve tended to let real interest rates decline or, at best, did not try to raise them. In other words, while the central bank did raise nominal rates, it did not do so sufficiently to raise real rates. ${ }^{24}$ This kind of response clearly does not stabilize inflation under any plausible view of the linkages between real rates, aggregate demand, output, and inflation ${ }^{25}$. Thus, according to

\footnotetext{
${ }^{24}$ Our finding of a less than one-for-one adjustment of the nominal rate to changes in expected inflation is closely related to the finding of a strong negative correlation between the estimated expected inflation rate and the estimated real rate by Mishkin [1981] and others in the context of an exploration of the Fisher hypothesis. Interestingly, the sample period in Mishkin's paper ends in 1979:4, just one quarter after Volcker began his tenure as Fed chairman!. Furthermore, in subsequent work, Huizinga and Mishkin [1986] show formally that there is a shift in interest rate behavior before and after October 1979.

${ }^{25}$ As we noted at the end of section II, if the Fed responds aggressively only large deviations of inflation from target but not to small deviations, then it may be possible to obtain an estimate of
} 
our results, the persistent and volatile behavior of inflation in the pre-Volcker era may be partly due to the monetary rule in place, independently of the nature of the fundamental shocks which may have impinged on the economy during that period.

By way of contrast, under the Volcker-Greenspan regime, the Federal Reserve has substantially raised target real rates in the wake of an anticipated increase in inflation (on a two-for-one basis, according to a rough average of our point estimates). To the extent that a rise in the real rate slows down the level of economic activity and relieves inflationary pressures, the interest rate policy in the Volcker-Greenspan era provides a natural explanation for the stability of inflation experienced by the US economy in recent years.

\section{Oil Shocks versus Monetary Policy}

Our analysis has emphasized how differences in monetary policy might account for differences in macroeconomic behavior pre- and post-1979. An alternative (though not incompatible) hypothesis points to the role of the two major oil shocks that occurred in1973 and in 1979. Indeed, Hamilton (1983) has argued forcefully that oil shocks are a central driving force in business cycles. This raises the question of whether the pattern of oil shocks alone could account for the shift in macroeconomic volatility.

For two distinct reasons, however, we believe that differences in monetary policy remain critical to the story. First, recent work by DeLong (1997), Bernanke, Gertler and Watson (1997) (BGW), Barsky and Killian (1998) (BK) and others questions the degree to which oil shocks can account for the events of the 1970s. Second, and perhaps more important, even if one accepts the view that the oil shocks were critical to the two major recessions, it would be difficult for these shocks to generate the kind of persistent inflation that arose in this era in the absence of an accommodating $\beta$ that is less than unity, even the the policy regime is geared toward stabilzing inflation. However, for this scenario to plausible, we should also observe little variation of inflation about target. This was clearly not the case in the Martin-Burns-Miller sample. 
monetary policy. We briefly elaborate on each point.

At a minimum, the notion that the oil shocks can largely account for the volatile behavior in output during 1970 s period is open to debate. While a major shock to the real price of oil preceded both the $74-75$ and $80-82$ recessions, it is also true that significant tightening of monetary policy preceded each of these downturns (see, e.g., BGW). The bottom line is that it is a non-trivial exercise to sort out the relative importance of the oil shocks versus monetary policy over this period. The original Hamilton (1983) evidence, which is based on a bivariate analysis of oil prices and output, does not confront this identification problem. Multivariate analyses, which among other things allows for an indicator of monetary policy, point to a significantly weaker role for oil shocks in output dynamics (see, e.g., BGW and the references therein). BGW, further, present evidence to suggest that the endogenous tightening of monetary policy in response to the oil price increases accounts for much of the subsequent downturn in output, as opposed to the direct impact of the oil shocks themselves. $^{26}$

While there is room to debate the importance of the oil shocks for real activity over this period, the case that these shocks alone account for the sustained high inflation is completely unpersuasive. Note first that the Hamilton evidence is silent on the link between the oil shocks and inflation. On the other hand, as DeLong (1997) emphasizes, timing considerations make the oil shocks suspect as the leading explanation for the inflation over this period. Figure III illustrates this point. The top panel plots three-quarter centered moving averages of the real oil price against

\footnotetext{
${ }^{26}$ Along these lines, both BGW and BK present evidence to suggest that the tightening of monetary policy in response to the non-oil commodity price shocks that preceded the oil shocks had a much greater role in the 1974-75 recession than did the oil shocks. BK argue further that easy monetary policy during 1972 induced the run-up in commodity prices. Finally, the long lag between the 1979 oil shock and the the $81-82$ recession makes questionable whether the former was central to the latter, especially given the sustained tightening of monetary policy over thie period. Further, the Carter credit controls appeared to have been at work during the brief downturn in 1980 .
} 
inflation over the period 1960:1 -1997:1. As DeLong argues, the initial build-up of inflation in the late 1960s and early 1970s occurs prior to the first oil shock. Indeed, until the time of the first oil shock in 1974, the real oil price is steadily declining, while inflation is steadily rising. The real oil price then remains constant until late 1979, the period of the second major oil shock. Note again that there is a steady rise in inflation over a three year period prior to this shock. In turn, the decline in inflation in the early 1980s appears to lead the decline in the real oil price. Formal evidence in BGW and BK supports this descriptive evidence. The same multi-variate analysis that suggests a modest effect of oil prices on output indicates an even weaker effect on inflation. ${ }^{27}$

Even assuming that the oil shocks played a critical role, the ultimate impact of these disturbances on output and inflation depends very much on the feedback monetary policy rule that is in place. It is hard to imagine, for example, that the 1973 oil shock alone could have generated high inflation up to the time of the second shock in 1979, in the absence of an accommodating monetary policy. We demonstrate this point explicitly in the next section. In particular, we show in the context of a small macro model that a supply shock can indeed induce persistent inflation under the estimated pre-Volcker rule, but not under the estimated Volcker-Greenspan rule. In this respect, the nature of the monetary policy rule must undoubtedly be a critical factor in the 1970 s period of stagflation.

Finally, Figure IV plots the behavior of the ex post real interest rate versus inflation (again using three quarter centered moving averages). Note that pre-1979, the real rate steadily declines as inflation rises. Conversely, the real rate rise sharply in late 1979, leading the subsequent decline in inflation. This picture is thus consistent

\footnotetext{
${ }^{27}$ In a multi-variate system that includes real GDP, the GDP deflator, non-oil commodity prices, the Federal Funds rate and Hamiltion's preferred index of oil shocks (the minimum of zero and the current oil price minus the largest price over the previous four quarters), the oil shock measure accounts for at best roughly ten percent of the variation in the GDP deflator over the period 1960:1 to 1984:4. Extending the sample to $1997: 4$ points to an even weaker effect of the oil shock.
} 
with our story, which emphasizes the switch in monetary policy from accommodating to combating inflation. ${ }^{28}$ In the next section we flesh out the implications of the differences in monetary policy pre- and post-Volcker, using a simple macroeconomic framework.

\section{Interest Rate Rules and Economic Fluctuations}

In this section we analyze some of the macroeconomic implications of the estimated monetary policy reaction functions. We do so in the context of a monetary business cycle model with sticky prices. We first present the model's equilibrium conditions, and then analyze how the properties depend on the monetary policy rule in place. A comprehensive analysis of the quantitative properties of the model is beyond the scope of the present paper. Instead, we choose to focus our attention on a specific, but (in our opinion) rather important and fascinating issue, namely, the extent to which the change in the systematic component of monetary policy across the pre-Volcker and the Volcker-Greenspan eras may explain some of the differences in the degree of macroeconomic instability, as reflected in the volatility measures reported in Table I.

\section{A. A Baseline Model}

Our baseline model is a version of the sticky price models found in King and Wolman [1996], Woodford [1996, 1998], and Yun [1996], among others. After loglinearization around a zero inflation steady state, the model's equilibrium conditions are summarized by the following equations (ignoring uninteresting constants):

$$
\pi_{t}=\delta E\left\{\pi_{t+1} \mid \Omega_{t}\right\}+\lambda\left(y_{t}-z_{t}\right)
$$

\footnotetext{
${ }^{28}$ Note that the monetary policy tightening prior to the $1974-75$ recession is quickly reversed, in contrast to the tightening prior to the 1980-82 downturn. Thus, although policy tightening may have played a role in the 1974-75 recession, the overall pattern pre-1979 is consistent with accommodation of inflation, as our formal evidence suggests.
} 


$$
\begin{gathered}
y_{t}=E\left[y_{t+1} \mid \Omega_{t}\right]-\frac{1}{\sigma}\left(r_{t}-E\left[\pi_{t+1} \mid \Omega_{t}\right]\right)+g_{t} \\
r_{t}^{*}=\beta E\left[\pi_{t+1} \mid \Omega_{t}\right]+\gamma x_{t} \\
r_{t}=\rho r_{t-1}+(1-\rho) r_{t}^{*}
\end{gathered}
$$

Equation (6) describes the change in the aggregate price level as a function of expected future inflation and the deviation of $(\log )$ output $y_{t}$ from its natural rate $z_{t}$, where the latter is defined as the level of output that would obtain under fully flexible prices. $^{29}$ It can be derived from the aggregation of optimal price-setting decisions by monopolistically competitive firms, in an environment in which each firm adjusts its price with a constant probability in any given period. ${ }^{30}$ Equation (7) combines a standard Euler equation for consumption with a market clearing condition. ${ }^{31}$ It is often interpreted as an IS schedule, determining the current output gap as a function of the ex-ante real rate and expected future output. In this context $g_{t}$ can be interpreted as an exogenous demand factor. We assume that both $z_{t}$ and $g_{t}$ follow stationary $\mathrm{AR}(1)$ process. Equations (8) and (9) specify the policy rule. They are the theoretical model's counterpart to (1) and (3). For simplicity, we restrict ourselves to the case of a one-period horizon $(k=q=1)$, and assume that all variables dated $t$ or earlier belong to information set $\Omega_{t}$.

Our objective here is to simulate the model under alternative policy rules. We use standard methods to solve for the equilibrium dynamics (see, e.g., Blanchard and Kahn [1980]). We then choose the non-policy parameters as follows. We set the quarterly discount factor equal to 0.99 , implying an annual risk-free rate of 4 percent. We set $\sigma$-the coefficient of relative risk aversion-to be equal to 1 , and $\lambda$-the output

\footnotetext{
${ }^{29}$ Galí and Gertler [1998] and Sbordone [1998] present some evidence suggesting that (6) provides a good first approximation to the dynamics of inflation in the United States.

${ }^{30}$ Such a price-setting structure was first introduced in Calvo [1983], and has been frequently adopted in macroeconomic applications as a simple, flexible way of introducing price stickiness. A similar forward-looking Phillips curve arises, however, under alternative price-setting assumptions (e.g., quadratic adjustment costs or deterministic time-dependent rules with staggered pricing).

${ }^{31}$ I assumes a CRRA period-utility with relative risk aversion parameter $\sigma$.
} 
elasticity of inflation equal to $0.3,{ }^{32}$ and the autoregressive coefficient of the $z_{t}$ and $g_{t}$ processes equal to 0.9 . We choose the policy parameters, $\beta, \gamma$, and $\rho$ to correspond to our estimated policy-reaction functions, depending on the regime we wish to analyze.

We first explore how the estimated rule for the pre-Volcker era opens up the possibility of self-fulfilling fluctuations. We then compare how the estimated preVolcker and Volcker-Greenspan rules affect the economy's response to fundamental disturbances.

\section{B. Interest Rate Rules and Endogenous Fluctuations}

As emphasized by Kerr and King [1995], Bernanke and Woodford [1997] and Clarida, Galí and Gertler [1997], the policy feedback rule itself may be a source of instability if the coefficient on the inflation gap, $\beta$, is below unity. Values of $\beta$ in this range lead to indeterminacy of the equilibrium, and raise the possibility of fluctuations in output and inflation around their steady state values that result from self-fulfilling: revisions in expectations. ${ }^{33}$ The intuition is straightforward: With $\beta$ below unity, a rise in anticipated inflation leads to a decline in the real interest rate. The decline in the real rate then stimulates aggregate demand which, in turn, induces a rise in inflation. The initial rise in expected inflation thus becomes self-confirmed.

Since the estimate of $\beta$ is consistently less than unity for the pre-Volcker rule, self-fulfilling fluctuations are possible in this regime. What do these fluctuations look like? Figure $\mathrm{V}$ displays simulated time series of the response of the economy to a

\footnotetext{
${ }^{32}$ There is no widespread consensus on the value of $\lambda$. Values found in the literature range from 0.05 (Taylor [1980]) to 1.22 (Chari et al. [1996]). Following Woodford [1996], we choose the intermediate value 0.30, which is consistent with the empirical findings in Roberts [1995].

${ }^{33}$ In Clarida, Galí, and Gertler (1997) it is shown that the unit threshold value for $\beta$ obtains exactly only when $\gamma=0$, i.e., when there is no systematic response to output variations. As we increase $\gamma$, the lower bound for $\beta$ goes down, though the deviation from unity is quantitatively very small (almost negligible), and independent of $\rho$. In addition, the range of $\beta$ values for which the equilibrium is unique also has an upper bound. In other words, an "excessive" response to changes in expected inflation may also lead to indeterminacy. This is the case emphasized by Bernanke and Woodford [1997].
} 
sequence of self-fulfilling revisions in inflationary expectations ("sunspot shocks"). We use the baseline estimates of the pre-Volcker regime to fix the parameters of the policy rule (first row of Table II). We draw the "sunspot shocks" to expectations from a standard normal distribution. Our 1997 working paper provides the details.

The figure reports the cyclical behavior of output, inflation and the nominal interest rate. Note that persistent fluctuations in output and inflation arise, despite the absence of any fundamental shocks ${ }^{34}$. In order to get some intuition for the mechanisms underlying these self-fulfilling fluctuations, Figure VI displays the impulse responses of several variables to a sunspot shock. The sunspot realization generates, on impact, an increase in expected inflation (as well as the anticipation of a slow return to its original level). Given the assumed policy rule, that forecast revision leads to a rise in the nominal rate, but the latter falls short of the increase in expected inflation throughout the entire adjustment process. As a result, the real rate shows a persistent decline, fueling an expansion in output and a rise in inflation, thus validating the initial increase in expected inflation. Over time, output gradually returns to trend, and so do the nominal rate and inflation, as well as the real rate.

By way of contrast, self-fulfilling fluctuations cannot arise under the estimated interest rate rule for the Volcker-Greenspan period. Because $\beta$ is well above unity in this regime, short term real rates cannot adjust to accommodates sunspot shifts in inflationary expectations, as they instead do under the estimated pre-Volcker policy. Under this type of regime, accordingly, macroeconomic fluctuations arise only in the presence of shocks to fundamentals. In other words, the monetary policy rule in place is not, in itself, a source of macroeconomic instability. On the other hand, the policy rule does affect how the economy responds to fundamental shocks. We explore this

\footnotetext{
${ }^{34}$ Generally speaking, the sunspot shocks give rise to positive co-movement between output and inflation. To account for the negative co-movement that occurred in the 1970s, it appears necessary to also mix in adverse supply shocks. As we make clear in the next subsection, however, supply shocks alone cannot account for the persistent inflation over this era: For them to do so, it is critical to also have an accomodating monetary policy.
} 
issue in the next section.

\section{Near-Indeterminacy and Fundamental Shocks}

As we have just seen, the point estimates for the inflation and output gap coefficients during the pre-Volcker era fall within the indeterminacy region of the canonical model presented above. This is true for all specifications considered. In some cases, however, the standard errors for the estimate of $\beta$ are too large to rule out the possibility that the true value is unity or slightly above. ${ }^{35}$ In this borderline instance the economy is just outside the region of indeterminacy.

Even though sunspot fluctuations are not feasible in this case, however, the economy is still likely to be relatively unstable under this kind policy regime. We illustrate this issue in the context of our calibrated model. In particular, we compute the implied standard deviation of inflation and output, under alternative values of $\beta$, the inflation coefficient and conditional on a given source of fluctuations (supply $z_{t}$, or demand $\left.g_{t}\right){ }^{36}$ Throughout this exercise, we keep both $\gamma$ and $\rho$ constant and equal to their estimated values for the pre-Volcker period under the baseline specification (i.e., 0.27 and 0.68 , respectively).

Table VIII reports the results. It shows how the standard deviations of output, inflation and the output gap vary in response to shifts in the feedback parameter $\beta$. The first three columns display the results conditional on the supply shock $z_{t}$ being the fundamental drive force. The last three columns repeat the exercise, this time with the demand shock. For ease of exposition, we normalize to unity the standard deviations corresponding to the calibration with $\beta=2.0$.

\footnotetext{
${ }^{35}$ In fact, it is possible to find combinations of rule specifications and subperiods within the preVolcker era for which the point estimate for $\beta$ is slightly above one (though not significantly so). We thank an anonymous referee for that observation, which encouraged us to conduct the robustness analysis found above.

${ }^{36} \mathrm{An}$ general analysis of the effectiveness and desirability of alternative interest rate rules in a model closely related to ours can be found in Rotemberg and Woodford [1997], among others. We differ by focusing on the implications of the feedback parameter on expected inflation.
} 
The results make it clear that the cyclical response of the economy to fundamental shocks is quite sensitive to $\beta$, especially over the estimated range of values across the pre-Volcker and Volcker-Greenspan periods. As $\beta$ rises from one to two, the volatility of both output and inflation declines by more than half. This occurs for both the supply shock and the demand shock. The reduction in volatility that the VolckerGreenspan rule achieves is thus quite substantial.

The intuition is straightforward: a value of $\beta$ equal or just above unity suggests that the central bank comes close to fully accommodating inflationary pressures, by raising nominal rates to keep real rates roughly constant. The absence of a strong stabilizing adjustment of the real rate suggests, in turn, that fundamental shocks may generate considerable volatility in inflation and the output gap, at least relative to the Volcker-Greenspan type policy, where the central bank adjusts real rates in a strongly countercyclical manner.

We next illustrate explicitly how the ability of supply shocks to generate stagflation (and hence account for the 1970s) depends on the nature of the monetary policy rule. Figure VII reports the response of inflation and output to a negative supply shock (negative shock to $z_{t}$ ) for several values of the feedback coefficient on expected inflation, $\beta$, that range from 1.01 to 2.00 . The key point is that the supply shock produces a persistent effect on inflation only for values of $\beta$ near unity. As $\beta$ rises to 2.00 , the supply shock has only a small transitory impact on inflation. In sum, how large and persistent is the response of inflation to the supply shock is quite sensitive to the feedback rule. The accommodating pre-Volcker policy, it appears, can account for a persistent response of inflation. The same does not appear to be true for the Volcker-Greenspan policy, as is consistent with our hypothesis

Finally, we note that the results we obtain in the context of our simple New Keynesian model are largely robust to using a much broader set of macroeconomic models. Two model features are critical, but they are features that are commonplace in most conventional macroeconomic frameworks: First, there must be an inverse 
relationship between output and the ex-ante real rate (i.e., an IS-type relationship). Second, there must be a positive short run link between output and inflation (i.e., a Phillips curve). Given these features, a monetary policy rule that accommodates inflationary pressures is, in general, more likely to bring about higher unconditional volatility of inflation and the output gap than otherwise. ${ }^{37}$

\section{Summary and Concluding Remarks}

In this paper we have provided an empirical characterization of the systematic component of United States monetary policy in the postwar era. In order to do so, we have estimated a simple forward looking policy reaction function.

Our estimates point to a significant difference in the way monetary policy was conducted pre and post late 1979. In the pre-Volcker years, the Fed typically raised nominal rates by less than any increase in expected inflation, thus letting real short term rates decline as anticipated inflation rose. On the other hand, during the VolckerGreenspan era the Fed raised real as well as nominal short term interest rates in response to higher expected inflation. Thus, our results lend quantitative support to the view that the anti-inflationary stance of the Fed has been stronger in the past two decades.

Finally, we have argued that the pre-Volcker rule may have contained the seeds of macroeconomic instability that seemed to characterize the late $60 \mathrm{~s}$ and $70 \mathrm{~s}$. In particular, in the context of a calibrated sticky price model, the pre-Volcker rule leaves open the possibility of bursts of inflation and output that result from self-fulfilling changes in expectations. At best, the pre-Volcker rule does a considerably worse job than the Volcker-Greenspan policy of insulating the economy from fundamental shocks.

\footnotetext{
${ }^{37}$ One difference that arises between the New Keynesian model and a simple backward looking Keynesian model (see, e.g, Svensson, 1996) is that, in the latter, self-fulfilling fluctuations are not possible since beliefs about the future do not affect behavior. In this instance, a feedback rule with $\beta<1$ simply leads to explosive behavior, utlimately necessitating a shift in the policy rule.
} 
One important question our paper raises but does not answer is the following: Why is it that during the pre-1979 period the Federal Reserve followed a rule that was clearly inferior ?. Another way to look at the issue is to ask why it is that the Fed maintained persistently low short term real rates in the face of high or rising: inflation. One possibility, emphasized by De Long [1997], is that the Fed thought the natural rate of unemployment at this time was much lower than it really was (or equivalently, that the output gap was much smaller). There is considerable anecdotal evidence to support this interpretation, though it is not clear why the Fed should have held this view over such a long period of time. Orphanides [1997] emphasizes that preliminary estimates of potential output are often quite different than revised estimates. One possibility, thus, is that during the 1970s the Federal Reserve had consistently overly-optimistic preliminary estimates of potential output. Again, one has to explain why the misforecast were so persistently one-sided.

Another somewhat related possibility is that, at that time, neither the Fed nor the economics profession understood the dynamics of inflation very well. ${ }^{38}$ Indeed, it was not until the mid-to-late 1970s that intermediate textbooks began emphasizing the absence of a long run trade-off between inflation and output. The ideas that expectations may matter in generating inflation and that credibility is important in policy-making were simply not well established during that era. What all this suggests is that in understanding historical economic behavior, it is important to take into account the state of policy-maker's knowledge of the economy and how it may have evolved over time. Analyzing policy-making from this perspective, we think, would be a highly useful undertaking. ${ }^{39}$

\section{COLUMBIA UNIVERSITY}

\footnotetext{
${ }^{38}$ See, e.g., Croushore [1996] for evidence of systematic bias in inflation forecasts during that period.

${ }^{39}$ Recent work in this direction can be found in Sargent [1998].
} 
NEW YORK UNIVERSITY AND UNIVERSITAT POMPEU FABRA NEW YORK UNIVERSITY 


\section{References}

Barsky, Rober, and Lutz Killian "Money, Stagflation and Oil Prices: A Re-Interpretation," unpublished manuscript, 1998.

Bernanke, Ben, and Ilian Mihov, "Measuring Monetary Policy," Quarterly Journal of Economics, CXIII (August 1998), 869-902.

Bernanke, Ben, and Michael Woodford, "Inflation Forecasts and Monetary Policy," Journal of Money, Credit and Banking, XXIV (1997), 653-684.

Bernanke, Ben, Mark Gertler, and Mark Watson, "Systematic Monetary Policy and the Effects of Oil Price Shocks," Brookings Papers on Economic Activity (1997), $91-157$.

Blanchard, Olivier and Charles M. Kahn, "The Solution of Linear Difference Models under Rational Expectations," Econometrica, XLVIII (1980), 1305-1311.

Calvo, Guillermo, "Staggered Prices in a Utility Maximizing Framework," Journal of Monetary Economics, XII (1983), 383-398.

Chari, V.V., Lawrence Christiano, and Martin Eichenbaum, "Expectation Traps and Discretion," Northwestern University, mimeo, 1997.

Chari, V.V., Patrick J. Kehoe, and Ellen R. McGrattan, "Sticky Price Models of the Business Cycle: Can the Contract Multiplier Solve the Persistence Problem," Federal Reserve Bank of Minneapolis, Staff Report 217, 1996.

Clarida, Richard, and Mark Gertler, "How the Bundesbank Conducts Monetary Policy," in C. Romer and D. Romer eds. Reducing Inflation: Motivation and Strategy (Chicago: Chicago University Press, 1996).

Clarida, Richard, Jordi Galí, and Mark Gertler, "Monetary Policy Rules and Macroeconomic Stability: Evidence and Some Theory," NBER Working Paper no. 6442, 1997. 
Clarida, Richard, Jordi Galí, and Mark Gertler, "Monetary Rules in Practice: Some International Evidence," European Economic Review, XLII (1998), 1033-1068.

Clarida, Richard, Jordi Galí, and Mark Gertler, "The Science of Monetary Policy: A New Keynesian Perspective," forthcoming in Journal of Economic Literature, 1999

Croushore, Dean, "Inflation Forecasts: How Good Are They?," Business Review, Federal Reserve Bank of Philadelphia, (1996), 15-25.

De Long, J. Bradford, “America's Peacetime Inflation: the 1970s" in C. Romer and D. Romer eds. Reducing Inflation: Motivation and Strategy, (Chicago: Chicago University Press, 1997).

Friedman, Benjamin M., and Kenneth N. Kuttner, "A Price Target for U.S. Monetary Policy? Lessons from the Experience with Money Growth Targets," Brookings Papers on Economic Activity, 126-134, 1996.

Fuhrer, Jeffrey C., and George R. Moore, "Inflation Persistence," Quarterly Journal of Economics, XLIV (1995), 127-159.

Galí, Jordi, and Mark Gertler "Inflation Dynamics: A Structural Econometric Analysis," mimeo, 1998.

Gertler, Mark, "Comments on Friedman and Kuttner" Brookings Papers on Economic Activity, 77-125, 1996.

Goodfriend, Marvin, "Interest Rates and the Conduct of Monetary Policy," CarnegieRochester Conference Series on Public Policy, XXXIV (1991), 7-30.

Hamilton, James D, "Oil Price and the Macroeconomy Since World War II," Journal of Political Economy XCI (1983): 228-48.

Hansen, Lars P., "Large Sample Properties of Generalized Method of Moments Estimators," Econometrica, L (1982), 1029-1054.

Huizinga, John and Frederic S. Mishkin, "Monetary Policy Regime Shifts and the Unususal Behavior of Real Interest Rates," Carnegie-Rochester Conference Series on 
Puiblic Policy, XXIV (1986), 231-274.

Kerr, William, and Robert G. King, "Limits on Interest Rate Rules in the IS Model," Economic Quarterly, LXXXII (1996), 47-76.

King, Robert G., and Alexander L. Wolman, "Inflation Targeting in a St. Louis Model of the 21st Century" NBER Working Paper no. 5507, 1996.

Leeper, Eric M., "Equilibria Under Active and Passive Monetary and Fiscal Policies," Journal of Monetary Economics, XXVII (1991), 129-147.

Mishkin, Frederic S., "The Real Interest Rate: an Empirical Investigation," CarnegieRochester Series on Public Policy, XV (1981), 151-200.

Orphanides, Athanasios, "Monetary Policy Rules Based on Real-Time Data," Federal Reserve Board, mimeo, 1997.

Roberts, John M., "New Keynesian Economics and the Phillips Curve," Journal of Money, Credit and Banking, XXVII (1995), 975-984.

Rotemberg, Julio, and Michael Woodford, "An Optimization-Based Econometric Framework for the Evaluation of Monetary Policy," NBER Macroeconomics Annual (Cambridge, MA: MIT Press, 1997).

Rudebusch, Glenn D., "Federal Reserve Interest rate Targeting, Rational Expectations, and the Term Structure," Journal of Monetary Economics, XXXV (1995), $245-274$.

Sack, Brian, "Uncertainty and Gradual Monetary Policy," Federal Reserve Board, mimeo, 1997.

Sargent, Thomas, "The Conquest of American Inflation," unpublished manuscript, 1998.

Sbordone, Argia, "Prices and Unit Labor Costs: A New Test of Sticky Prices," mimeo, 1998. 
Svensson, Lars E.O., "Inflation Forecast Targeting: Implementing and Monitoring Inflation Targets," NBER Working Paper No. 5797, 1996.

Taylor, John B. "Aggregate Dynamics and Staggered Contracts," Journal of Political Economy, LXXXVIII (1980), 1-23.

Taylor, John B., "Discretion versus Policy Rules in Practice" Carnegie-Rochester Series on Public Policy XXXIX (1993), 195-214.

Woodford, Michael, "Stationary Sunspot Equilibria: the Case of Small Fluctuations around a Deterministic Steady State," unpublished manuscript, 1986.

Woodford, Michael, "Control of the Public Debt: A Requirement for Price Stability ?" NBER Working Paper No. 5684, 1996.

Woodford, Michael, "Optimal Monetary Policy Inertia," unpublished manuscript, 1998.

Yun, Tack "Nominal Price Rigidity, Money Supply Endogeneity, and Business Cycles," Journal of Monetary Economics, XXXVII (1996), 345-370. 
TABLE I

AGGREGATE VOLATILITY INDICATORS

\begin{tabular}{|c|c|c|c|c|}
\hline & \multicolumn{4}{|c|}{ Standard Deviation of: } \\
\hline & \multicolumn{2}{|c|}{ Inflation } & \multicolumn{2}{|c|}{ Output } \\
\hline & level & $h p$ & $g a p$ & $h p$ \\
\hline Pre-Volcker & 2.77 & 1.48 & 2.71 & 1.83 \\
\hline Volcker-Greenspan & 2.18 & 0.96 & 2.36 & 1.49 \\
\hline post-82 & 1.00 & 0.79 & 2.06 & 1.34 \\
\hline
\end{tabular}


TABLE II

BASELINE ESTIMATES

\begin{tabular}{lccccc}
\hline \hline & & & & & \\
& $\pi^{*}$ & $\beta$ & $\gamma$ & $\rho$ & $p$ \\
\hline \multirow{3}{*}{ Pre-Volcker } & 4.24 & 0.83 & 0.27 & 0.68 & 0.834 \\
& $(1.09)$ & $(0.07)$ & $(0.08)$ & $(0.05)$ & \\
& & & & & \\
Volcker-Greenspan & 3.58 & 2.15 & 0.93 & 0.79 & 0.316 \\
& $(0.50)$ & $(0.40)$ & $(0.42)$ & $(0.04)$ & \\
& & & & & \\
\hline \hline
\end{tabular}

Standard errors reported in brackets. The set of instruments includes four lags of inflation, output gap, the federal funds rate, the short-long spread, commodity price inflation and wage inflation. 
TABLE III

ALTERNATIVE VARIABLES

\begin{tabular}{|c|c|c|c|c|c|}
\hline & $\pi^{*}$ & $\beta$ & $\gamma$ & $\rho$ & $p$ \\
\hline \multicolumn{6}{|l|}{ Detrended Output } \\
\hline Pre-Volcker & $\begin{array}{c}4.17 \\
(0.68)\end{array}$ & $\begin{array}{c}0.75 \\
(0.07)\end{array}$ & $\begin{array}{c}0.29 \\
(0.08)\end{array}$ & $\begin{array}{c}0.67 \\
(0.05)\end{array}$ & 0.801 \\
\hline Volcker-Greenspan & $\begin{array}{c}4.52 \\
(0.58)\end{array}$ & $\begin{array}{c}1.97 \\
(0.32)\end{array}$ & $\begin{array}{c}0.55 \\
(0.30)\end{array}$ & $\begin{array}{c}0.76 \\
(0.05)\end{array}$ & 0.289 \\
\hline \multicolumn{6}{|l|}{ Unemployment Rate } \\
\hline Pre-Volcker & $\begin{array}{c}3.80 \\
(0.87)\end{array}$ & $\begin{array}{c}0.84 \\
(0.05)\end{array}$ & $\begin{array}{c}0.60 \\
(0.11)\end{array}$ & $\begin{array}{c}0.63 \\
(0.04)\end{array}$ & 0.635 \\
\hline Volcker-Greenspan & $\begin{array}{c}4.42 \\
(0.44)\end{array}$ & $\begin{array}{c}2.01 \\
(0.28)\end{array}$ & $\begin{array}{c}0.56 \\
(0.41)\end{array}$ & $\begin{array}{c}0.73 \\
(0.05)\end{array}$ & 0.308 \\
\hline \multicolumn{6}{|l|}{ CPI } \\
\hline Pre-Volcker & $\begin{array}{c}4.56 \\
(0.53)\end{array}$ & $\begin{array}{c}0.68 \\
(0.06)\end{array}$ & $\begin{array}{c}0.28 \\
(0.08)\end{array}$ & $\begin{array}{c}0.65 \\
(0.05)\end{array}$ & 0.431 \\
\hline Volcker-Greenspan & $\begin{array}{c}3.47 \\
(0.79)\end{array}$ & $\begin{array}{c}2.14 \\
(0.52)\end{array}$ & $\begin{array}{c}1.49 \\
(0.87)\end{array}$ & $\begin{array}{c}0.88 \\
(0.03)\end{array}$ & 0.138 \\
\hline
\end{tabular}

Standard errors reported in brackets. The set of instruments includes four lags of inflation, output gap, the federal funds rate, the short-long spread, commodity price inflation and wage inflation. 
TABLE IV

ALTERNATIVE HORIZONS

\begin{tabular}{cccccc}
\hline \hline & & & & & \\
& $\pi^{*}$ & $\beta$ & $\gamma$ & $\rho$ & $p$ \\
\hline $\mathbf{k}=\mathbf{4}, \mathbf{q}=\mathbf{1}$ & & & & & \\
Pre-Volcker & 3.58 & 0.86 & 0.34 & 0.73 & 0.835 \\
& $(1.42)$ & $(0.05)$ & $(0.08)$ & $(0.04)$ & \\
& & & & & \\
& 3.25 & 2.62 & 0.83 & 0.78 & 0.876 \\
Volcker-Greenspan & $(0.23)$ & $(0.31)$ & $(0.28)$ & $(0.03)$ & \\
& & & & & \\
$\mathbf{k}=4, \mathbf{q}=\mathbf{2}$ & 3.32 & 0.88 & 0.34 & 0.73 & 0.833 \\
Pre-Volcker & $(1.80)$ & $(0.06)$ & $(0.09)$ & $(0.04)$ & \\
& & & & & \\
& 3.21 & 2.73 & 0.92 & 0.78 & 0.886 \\
Volcker-Greenspan & $(0.21)$ & $(0.34)$ & $(0.31)$ & $(0.03)$ & \\
& & & & & \\
\hline \hline
\end{tabular}

Standard errors reported in brackets. The set of instruments includes four lags of inflation, output gap, the federal funds rate, the short-long spread, commodity price inflation and wage inflation. 
TABLE $\mathrm{V}$

UNRESTRICTED INTERCEPT

\begin{tabular}{lccccc}
\hline \hline & $\alpha$ & $\beta$ & $\gamma$ & $\rho$ & $p$ \\
\hline \multirow{3}{*}{ Pre-Volcker } & 2.19 & 0.68 & 0.28 & 0.65 & 0.431 \\
& $(0.29)$ & $(0.06)$ & $(0.08)$ & $(0.05)$ & \\
& & & & & \\
Volcker-Greenspan & -0.27 & 2.14 & 1.49 & 0.88 & 0.138 \\
& $(1.66)$ & $(0.52)$ & $(0.87)$ & $(0.03)$ & \\
& & & & & \\
\hline \hline
\end{tabular}

Standard errors reported in brackets. The set of instruments includes four lags of inflation, output gap, the federal funds rate, the short-long spread, commodity price inflation and wage inflation. 
TABLE VI

SUBSAMPLE STABILITY

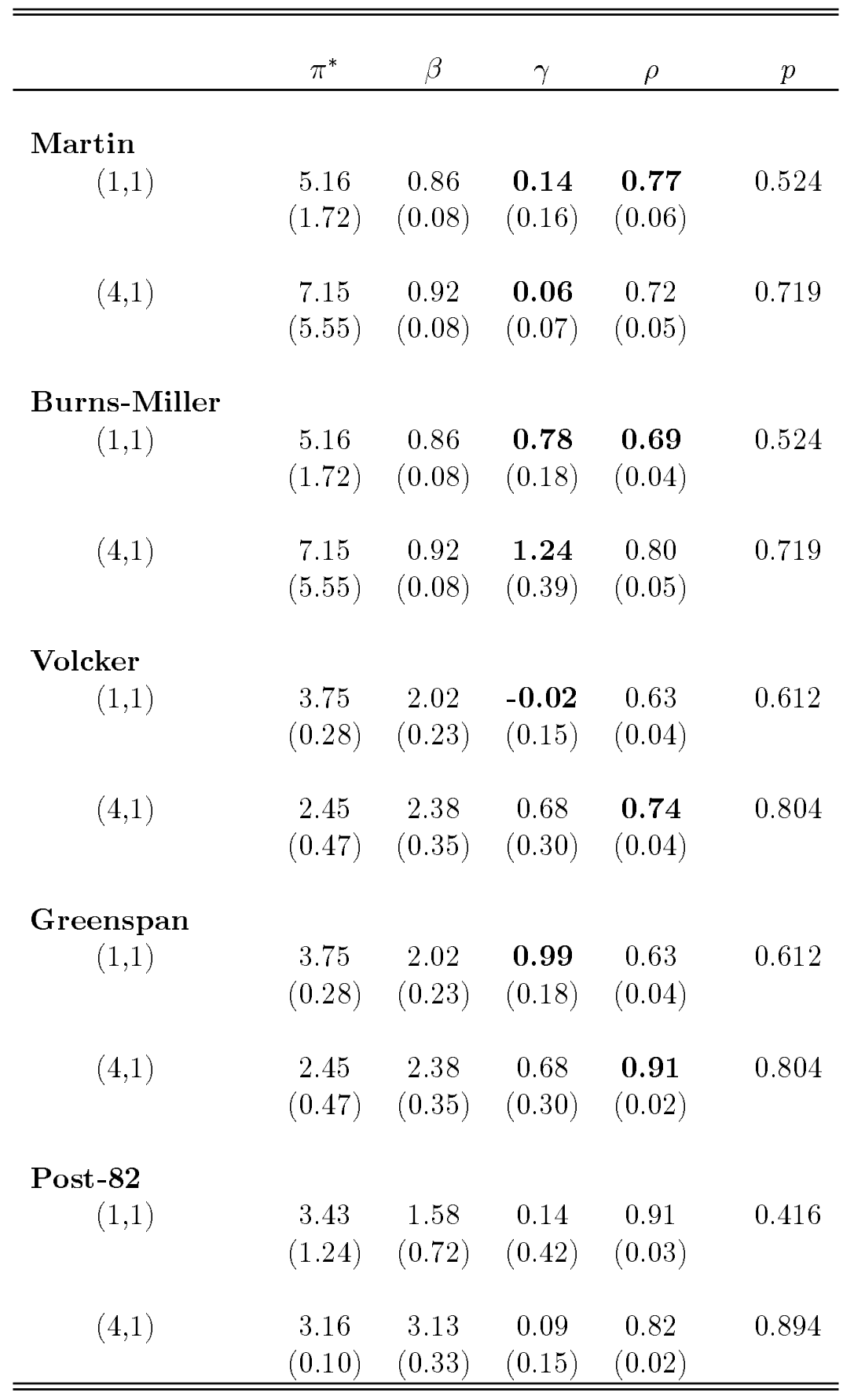

Standard errors reported in brackets. The set of instruments includes two lags of inflation, output gap, the federal funds rate, the short-long spread, commodity price inflation, and wage inflation, as well as the same variables with a multiplicative subperiod dummy. 
TABLE VII

BACKWARD LOOKING ESTIMATES

\begin{tabular}{lccccc}
\hline \hline & & & & & \\
& $\pi^{*}$ & $\beta$ & $\gamma$ & $\rho$ & $p$ \\
\hline \multirow{2}{*}{ Pre-Volcker } & 5.95 & 0.86 & 0.39 & 0.68 & 0.590 \\
& $(1.92)$ & $(0.07)$ & $(0.08)$ & $(0.05)$ & \\
& & & & & \\
Volcker-Greenspan & 4.08 & 1.72 & 0.34 & 0.71 & 0.307 \\
& $(0.56)$ & $(0.28)$ & $(0.19)$ & $(0.05)$ & \\
Post-82 & 2.96 & 2.55 & -0.15 & 0.89 & 0.486 \\
& $(0.27)$ & $(0.56)$ & $(0.28)$ & $(0.03)$ & \\
& & & & & \\
\hline \hline
\end{tabular}

Standard errors reported in brackets. The set of instruments includes four lags of inflation, output gap, the federal funds rate, the short-long spread, commodity price inflation and wage inflation. 
TABLE VIII

FUNDAMENTAL SHOCKS

\begin{tabular}{cccccc}
\hline \hline & \multicolumn{3}{c}{ Supply Shocks } & \multicolumn{2}{c}{ Demand Shocks } \\
$\beta$ & $\sigma(\pi)$ & $\sigma(x)$ & $\sigma(y)$ & $\sigma(\pi)$ & $\sigma(y)$ \\
\hline 2.0 & 1.00 & 1.00 & 1.00 & 1.00 & 1.00 \\
1.5 & 1.48 & 1.36 & 1.29 & 1.61 & 1.67 \\
1.1 & 2.57 & 2.16 & 2.26 & 3.04 & 1.96 \\
1.0 & 3.20 & 2.61 & 2.88 & 3.88 & 4.25 \\
\hline \hline
\end{tabular}


Figure I

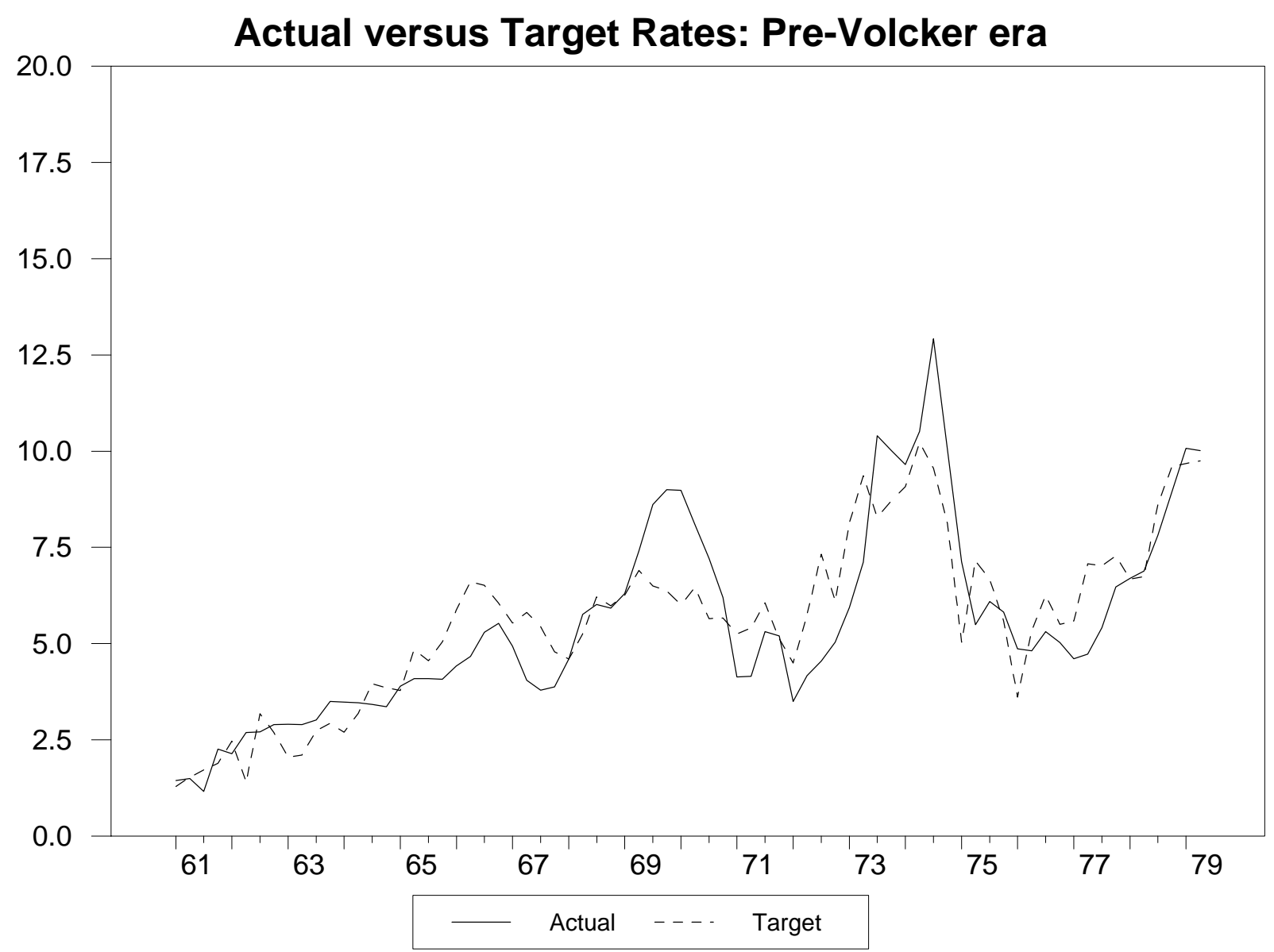


Figure II

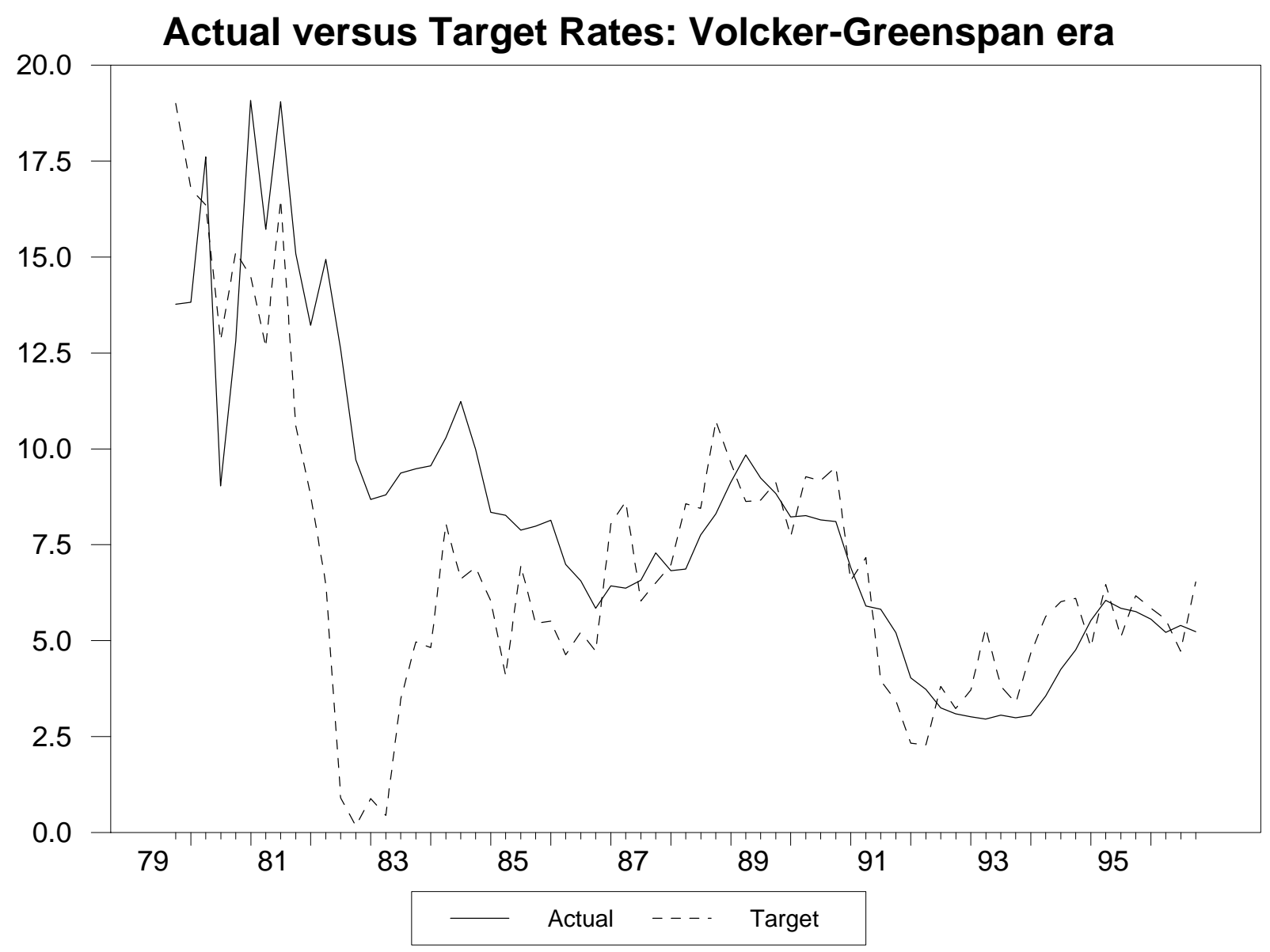


Figure III: Real Oil Price and Inflation

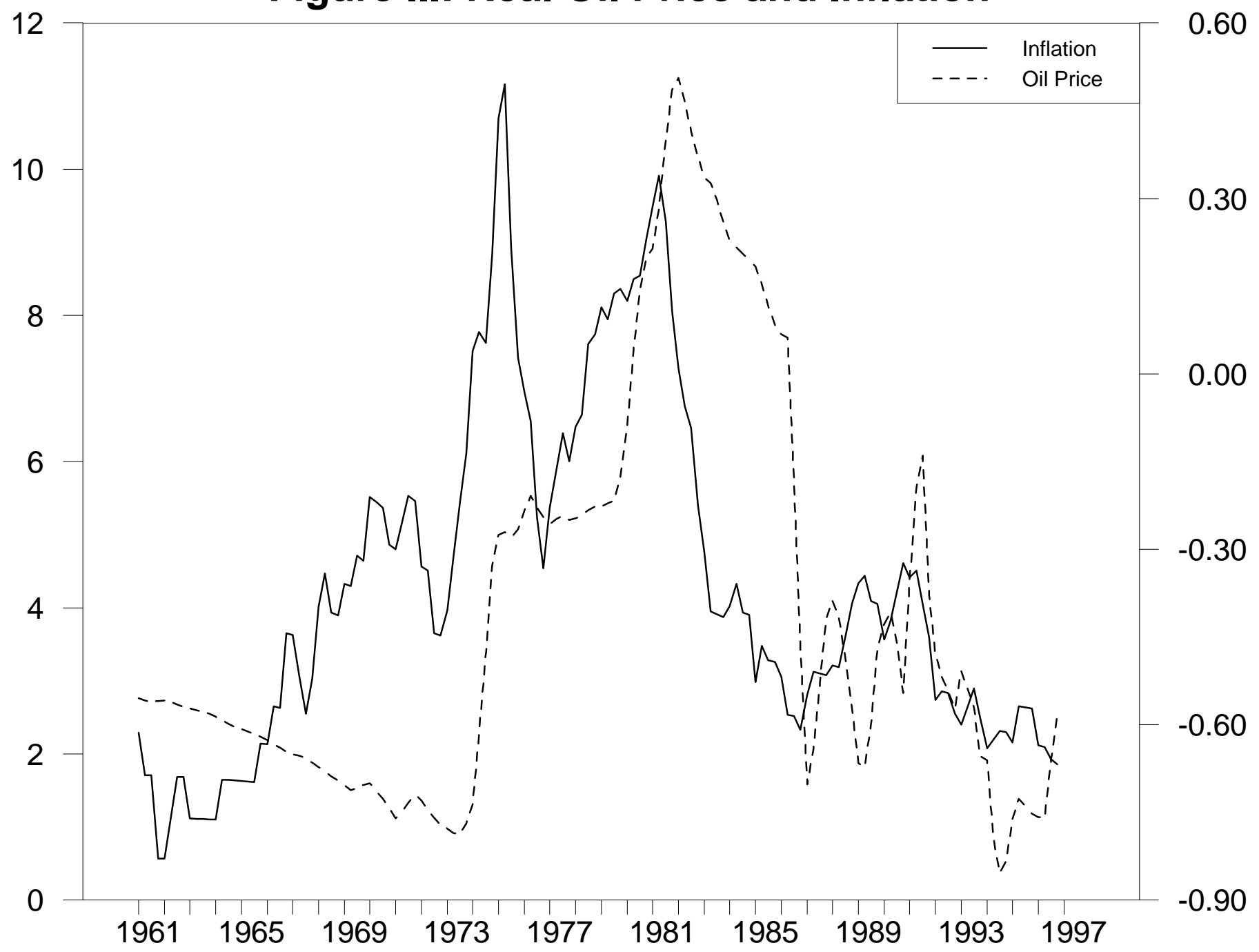


Figure IV: The Real Interest Rate and Inflation

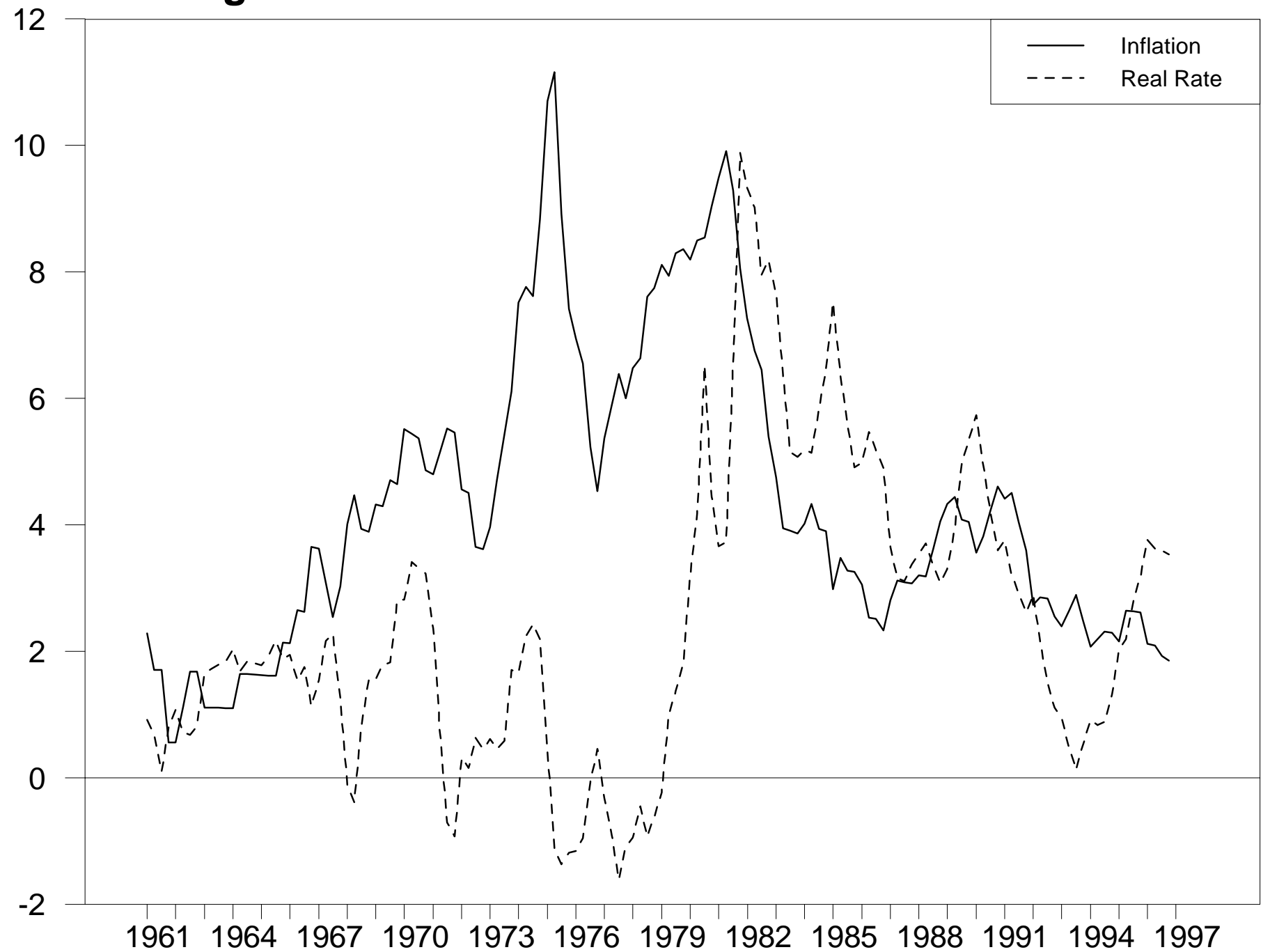


Figure VII: Impulse Responses to a Supply Shock

Inflation

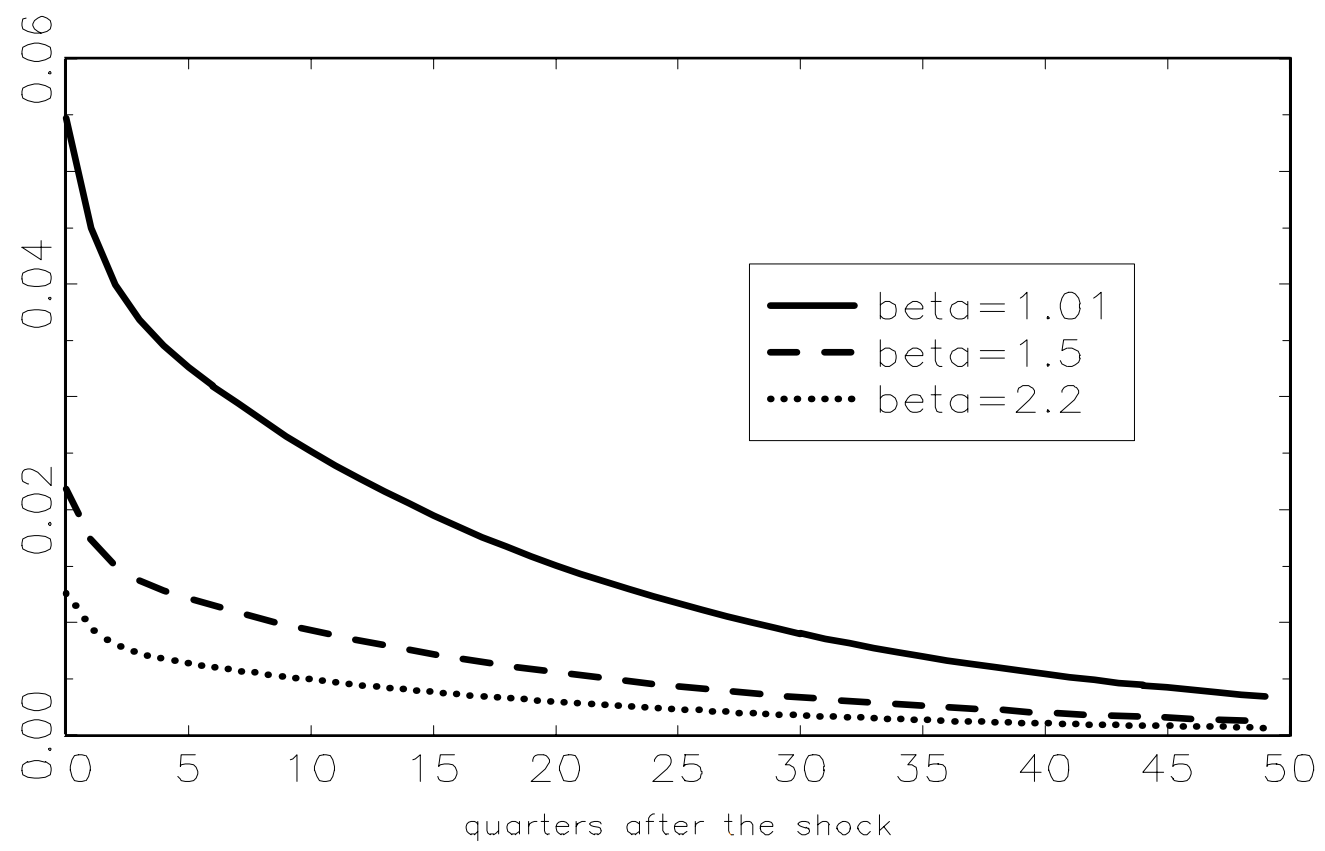

Output

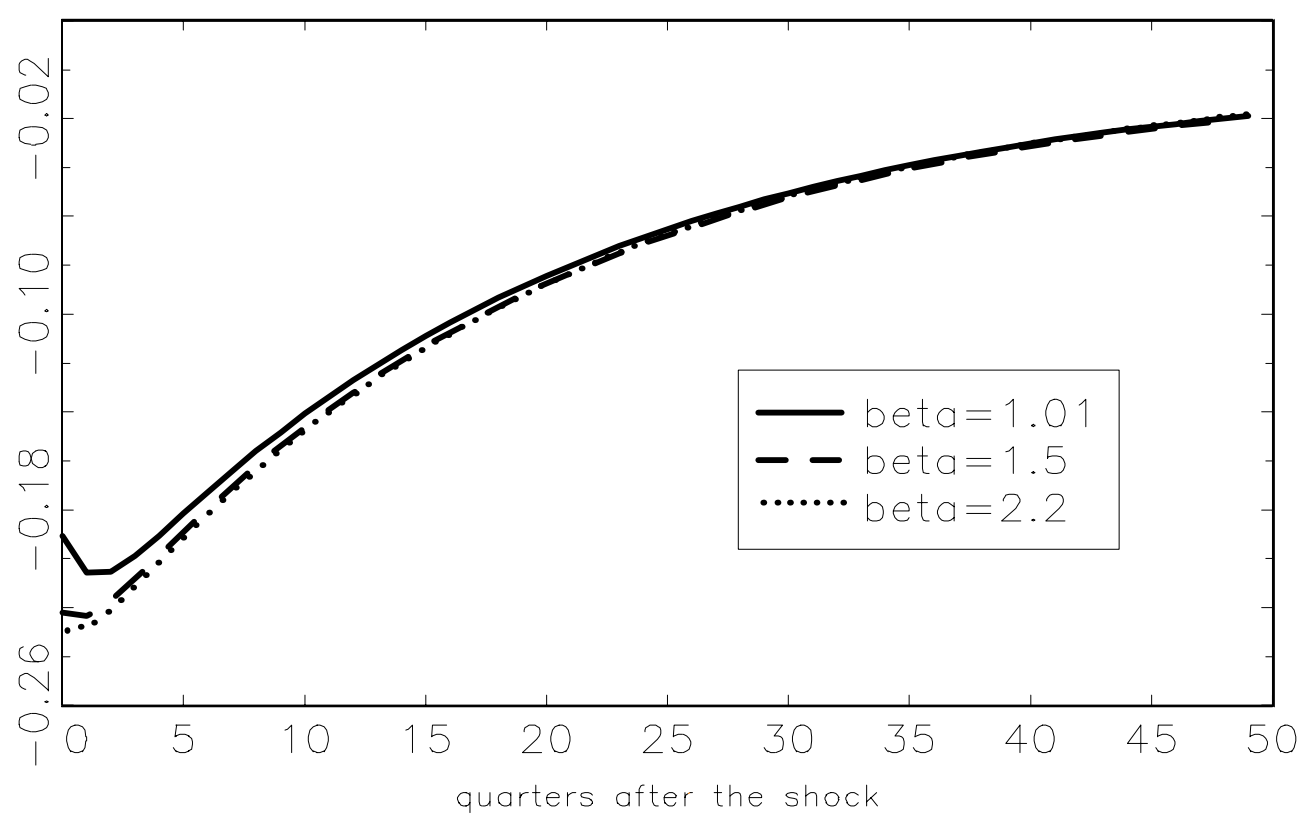

